\section{Impact of biosynthesized silver nanoparticles on protein and carbohydrate contents in seeds of Pisum sativum L.}

\section{Ansar Mehmood ${ }^{1 *}$ and Ghulam Murtaza ${ }^{2}$}

\begin{abstract}
Understanding the effects of nanoparticles on edible crops is a matter of importance, since nanoparticles are often released and spread in the environment because of extensive research. This study aimed to examine the effect of silver nanoparticles on protein and carbohydrate contents of Pisum sativum $L$. seed. Spherical crystalline silver nanoparticles were synthesized from aqueous root bark extract of Berberis lycium Royle. Three pea varieties (Climax, Meteor and PF-400) were treated with four concentrations of silver nanoparticles $(0,30$, 60 , and $90 \mathrm{ppm}$ ) and three modes of application, in a randomized complete block design with three replications, in the 2013-14 and 2014-15 growing seasons. Seeds were harvested at the end of the growing seasons and analyzed for total proteins and carbohydrates. A significant increase in protein and carbohydrate contents of harvested seeds was recorded. This study shows that the application of silver nanoparticles might revolutionize agriculture in the future.
\end{abstract}

Key words: Silver nanoparticles, metabolites, Pisum sativum.

\section{INTRODUCTION}

The field of nanotechnology is growing day by day and opens advanced research in many fields of science. Nanoparticles have found novel applications in different branches of sciences including biotechnology and agriculture. In agriculture, usually chemical fertilizers are used for better growth and development but major amount of used fertilizers becomes inaccessible to crops because of many aspects, like hydrolysis, degradation and leaching. Also their high cost cannot ensure economically viable and profitable agricultural products (Bobade et al. 1992). Hence, it is essential to diminish nutrient losses after fertilization, and to rise crop yields by the utilization of new technologies, such as applications of nanotechnology and nanomaterials. These materials have properties that can be exploited to protect plants, improve crop growth and yield, detect their diseases, enhance world food production, and improve food quality (Gruère et al. 2011, Prasad et al. 2014). The unique physiochemical properties of nanoparticles make them potential candidates to boost the plant metabolism (Giraldo et al. 2014).

Pisum sativum L. (field pea), of the family Fabaceae and native to Southwest Asia, was among the first crops cultivated by man. It is a winter-season annual crop. Most pea cultivars produce self-pollinated reddish purple or white flowers. The number of seeds ranges from 5 to 9 per pod (Zohary and Hopf 2000). Peas are a good source of nutrition, as the seed is rich in protein (27.8\%), vitamins,
Crop Breeding and Applied Biotechnology 17: 334-340, 2017 Brazilian Society of Plant Breeding. Printed in Brazil http://dx.doi.org/10.1590/198470332017v17n4a51 
Impact of biosynthesized silver nanoparticles on protein and carbohydrate contents in seeds of Pisum sativum L.

carbohydrates (42.65\%), minerals, dietary fibers, and antioxidant compounds (Urbano et al. 2003). In Pakistan, pea is a crop grown on plains in winter and on highlands in summer. It is an important vegetable, cultivated in Pakistan on an area of 10,478 hectares, with a total production of 71,792 tons and an average yield of 6.9 tons per hectare. Punjab as a leading province in pea production accounts for about $71 \%$ of the total output. Pea production in Pakistan is very low, compared to that of most of the other countries. Therefore, there is a great need to introduce environmentally safe methods for improving crops to meet the food demand of the nation. In this research, silver nanoparticles were used instead of chemical fertilizers to increase seed protein and carbohydrate contents in peas.

\section{MATERIAL AND METHODS}

Silver nanoparticles were synthesized via a biological route using root bark of the evergreen shrub Berberis lycium. Aqueous root bark extract was treated with $1 \mathrm{mM} \mathrm{AgNO}_{3}$ at room temperature. The synthesized silver nanoparticles (AgNPs) were characterized by UV-visible spectroscopy and scanning electron microscopy.

The impact of biosynthesized AgNPs on protein and carbohydrate contents in seeds of three pea varieties (Climax, Meteor and PF-400) was examined in split-split randomized complete block design. The experiment was performed during two growing seasons (2013-14 and 2014-15) in field area of Muzaffarabad. The seeds of each variety were obtained from Department of Agriculture, State of Azad Jammu and Kashmir. The main plots were allotted to pea varieties, sub plots to means of applications such as seed treatment, foliar spray and seed treatment plus foliar spray and sub-sub plots to concentrations of AgNPs such as 0, 30, 60 and $90 \mathrm{ppm}$. Each sub-subplot measured $3 \times 1.8 \mathrm{~m}^{2}$ $\left(5.4 \mathrm{~m}^{2}\right)$, the distance was maintained as $90 \mathrm{~cm}$ row-to-row distance and $15 \mathrm{~cm}$ plant-to-plant (Hussain and Badshah 2002). Each sub-subplot consisted of two rows and each row had 20 plants. All agronomic practices were carried out as and when needed.

The seeds were treated by soaking in AgNPs solution at 0, 30, 60 and $90 \mathrm{ppm}$ for $6 \mathrm{~h}$ (Benavides-Mendoza et al. 2002). Two phenological stages were selected for spraying the plants with AgNPs concentrations $(0,30,60$ and $90 \mathrm{ppm})$ such as BBCH 11 (first true leaf unfolded or first tendril developed) and BBCH 60 (first flower open sporadically within the population) in the early morning. $\mathrm{BBCH}$ means Biologische Bundesanstalt, Bundessortenamt und Chemische Industrie. A manual pump was used for spraying in all cases (Gutierrez-Coronado et al. 1998). Seeds obtained from the crops were analyzed for protein and carbohydrate contents.

\section{Protein assay}

Fresh seeds obtained from the crops were frozen and homogenized in ice cooled mortar and pestle with quartz sand at $4{ }^{\circ} \mathrm{C}$. Total proteins were extracted with $100 \mathrm{mM}$ tris- $\mathrm{HCL}$ buffer $(\mathrm{pH} 8.0)$ containing $150 \mathrm{mM} \mathrm{NaCl}$ and $1 \mu \mathrm{mL}^{-1}$ a-mercapto-ethanol. Proteins were extracted in the dark for $15 \mathrm{~min}$, centrifuged at $15,000 \mathrm{~g}$ at $4{ }^{\circ} \mathrm{C}$ for $20 \mathrm{~min}$ (Schlereth et al. 2000). The supernatant was stored for subsequent analysis. The protein content was determined by a protein-dyebinding assay (Bradford 1976). The color of Coomassie brilliant blue G250 in dilute acid solution changes proportionally as the dye binds to protein. Bradford reagent will be prepared by dissolving $50 \mathrm{mg}$ Coomassie Blue dye in a mixture of $50 \mathrm{~mL}$ of $85 \%$ a-phosphoric acid and $25 \mathrm{ml}$ of $95 \%$ methanol to a final volume of $500 \mathrm{~mL}$ with distilled water. Bovine Serum Albumin (1 mg mL ${ }^{-1}$ ) was used as standard. Absorbance was measured at $595 \mathrm{~nm}$ using a spectrophotometer.

\section{Carbohydrate assay}

The carbohydrate contents of pea seeds were determined by the phenol-sulphuric acid method defined by Krishnaveni et al. (1984). The seeds ( $100 \mathrm{mg}$ ) were boiled in $5 \mathrm{ml} 2.5 \mathrm{~N} \mathrm{HCl}$ in water bath for $3 \mathrm{~h}$, cooled and then neutralized using solid sodium carbonate. The final volume was completed to $100 \mathrm{~mL}$ and centrifuged. After centrifugation, $0.1 \mathrm{~mL}$ of the supernatant was pipetted out into a test tube. The test tube volume was completed to $1 \mathrm{ml}$ with distilled water. Then 1 $\mathrm{ml}$ phenol and $96 \% \mathrm{H}_{2} \mathrm{SO}_{4}$ were added. After $10 \mathrm{~min}$, the test tube was placed in water at $20^{\circ} \mathrm{C}$ for $20 \mathrm{~min}$. After cooling the solution, absorbance was measured at $490 \mathrm{~nm}$ wavelength, with sugar as standard.

The data obtained was subjected to analysis of variance and means were separated by Duncan's multiple range test using the MSTAT-C program (Steel et al. 1996). 


\section{RESULTS AND DISCUSSION}

\section{Synthesis of silver nanoparticles}

For the synthesis of AgNPs, $20 \mathrm{ml}$ root bark extract was added to $100 \mathrm{ml}$ of $1 \mathrm{mM} \mathrm{AgNO}$, solution. The first visual sign for the formation of silver nanoparticles was the color change of the reaction mixture, to a yellowish dark color (Figure 1). The yellowish brown color suggests the synthesis of silver nanoparticles (Shankar et al. 2004) and was further examined by UV-visible spectroscopy, after zero and $6 \mathrm{~h}$ of reaction (Figure 2). A definite absorption peak was noted after $6 \mathrm{~h}$ of reaction, indicating the increasing concentration of silver nanoparticles in the solution. The absorption band was centered at $\lambda_{\max } 422 \mathrm{~nm}$. It is already known that silver nanoparticles in the aqueous solution are defined by an absorption spectrum in the range of 400 to $450 \mathrm{~nm}$ (Zargar et al. 2011). It was also suggested that frequency and width of the surface plasmon resonance (SPR) absorption are correlated with the morphology and size of the nanoparticles (Teponno et al. 2006). The morphological characterization was achieved through scanning electron microscopy (Figure 3). The resulting nanoparticles were spheroid, with an average size of $54 \mathrm{~nm}$.

\section{Effect of silver nanoparticles on seed protein and carbohydrate}

A statistically significant enhancing effect of silver nanoparticles was found on protein and carbohydrate contents of $P$. sativum seeds during the growing seasons of 2013-14 and 2014-15 (Table 1). The highest seed protein content in relation to seed fresh weight (FW) was observed for variety PF-400 (109.45 $\left.\mu \mathrm{g} \mathrm{g} \mathrm{g}^{-1} \mathrm{FW}\right)$, followed by Climax (98.43 $\mathrm{ug} \mathrm{g}^{-1} \mathrm{FW}$ ) and Meteor (78.81 $\mathrm{\mu g} \mathrm{g}^{-1} \mathrm{FW}$ ) during 2013-14. PF-400 and Climax did not differ significantly from each other, but both differed significantly from Meteor in terms of seed protein content. During the following growing season, a similar trend was observed. PF-400 had the highest protein content (104.18 $\left.\mu \mathrm{g} \mathrm{g}^{-1} \mathrm{FW}\right)$, followed by Climax ( $\left.97.78 \mu \mathrm{g} \mathrm{g}^{-1} \mathrm{FW}\right)$ and Meteor $\left(79.49 \mu \mathrm{g} \mathrm{g}^{-1} \mathrm{FW}\right)$. All varieties differed significantly from each other, except PF-400 and Climax, which did not differ significantly from each other in seed protein content.

A significant effect was also found for the applied concentrations of silver nanoparticles. During 2013-14, the highest protein content was recorded for plants treated with 60 ppm AgNPs (106.14), which were significantly different from plants treated with AgNPs $90 \mathrm{ppm}\left(99.14 \mu \mathrm{g} \mathrm{g}^{-1} \mathrm{FW}\right), 30 \mathrm{ppm}\left(93.13 \mu \mathrm{g} \mathrm{g}^{-1} \mathrm{FW}\right)$ and $0 \mathrm{ppm}\left(83.86 \mu \mathrm{g} \mathrm{g}^{-1}\right.$ FW). All silver nanoparticle concentrations differed from each other in terms of induced seed protein contents. During the $2^{\text {nd }}$ growing season, the highest seed protein content was found for plants treated with $60 \mathrm{ppm} \mathrm{AgNPs}(104.49 \mu \mathrm{g}$ $\left.\mathrm{g}^{-1} \mathrm{FW}\right)$, followed by plants treated with $90 \mathrm{ppm}\left(97.58 \mu \mathrm{g} \mathrm{g}^{-1} \mathrm{FW}\right), 30 \mathrm{ppm}\left(91.41 \mathrm{\mu g} \mathrm{g}^{-1} \mathrm{FW}\right)$ and $0 \mathrm{ppm}\left(81.78 \mu \mathrm{g} \mathrm{g}^{-1}\right.$

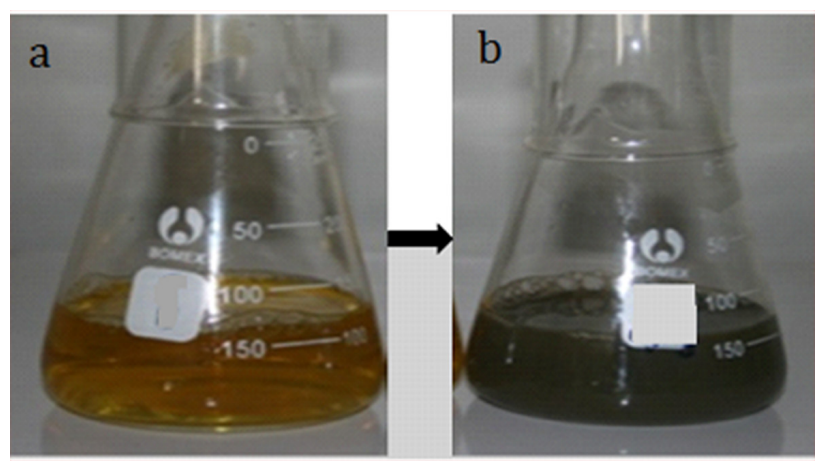

Figure 1. Color of plant extract before (a) and (b) after adding $\mathrm{AgNO}_{3}$ solution.

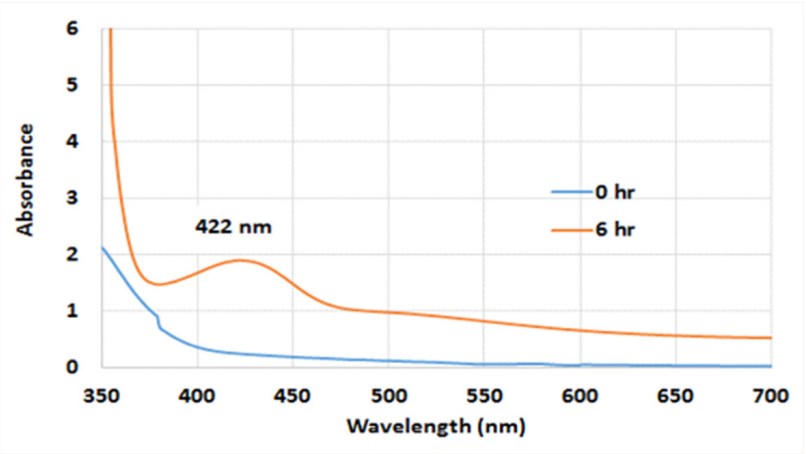

Figure 2. UV-visible spectrograph of silver nanoparticles after 0 and 6 hours.

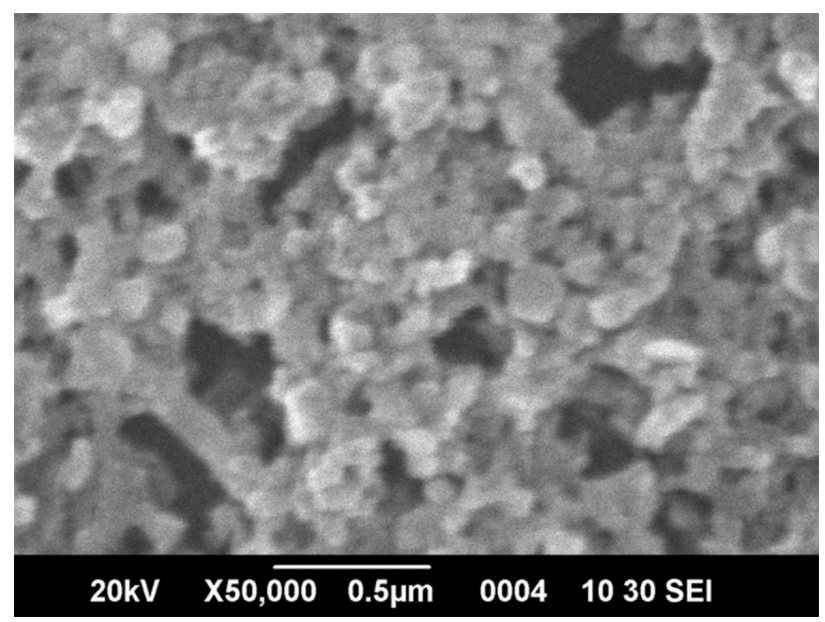

Figure 3. SEM image of silver nanoparticles. 
Impact of biosynthesized silver nanoparticles on protein and carbohydrate contents in seeds of Pisum sativum L.

Table 1. Effect of AgNPs on protein content ( $\left.\mathrm{gg} \mathrm{g}^{-1} \mathrm{FW}\right)$ of Pisum sativum L. (pea) varieties during growing season $2013-14$ and $2014-15$

\begin{tabular}{|c|c|c|c|c|c|c|c|c|}
\hline \multirow[b]{2}{*}{ Varieties } & \multicolumn{4}{|c|}{ Growing season 2013-14* } & \multicolumn{4}{|c|}{ Growing season 2014-15* } \\
\hline & ST & FS & STFS & Means & ST & FS & STFS & Means \\
\hline Climax & 99.7 & 93.9 & 101.5 & $98.4 \mathrm{~A}$ & 93.8 & 93.4 & 106.0 & $97.7 \mathrm{~A}$ \\
\hline Meteor & 74.9 & 75.5 & 85.9 & $78.8 \mathrm{~B}$ & 77.0 & 75.1 & 86.2 & $79.4 \mathrm{~B}$ \\
\hline PF-400 & 112.1 & 98.8 & 117.3 & $109.4 \mathrm{~A}$ & 103.6 & 91.9 & 116.9 & $104.1 \mathrm{~A}$ \\
\hline \multicolumn{9}{|c|}{ AgNPs Concentrations } \\
\hline $0 \mathrm{ppm}$ & $84.1 \mathrm{c}$ & $82.0 \mathrm{~g}$ & $85.3 \mathrm{fg}$ & $83.8 \mathrm{D}$ & $79.3 \mathrm{~g}$ & $78.1 \mathrm{~g}$ & $87.8 \mathrm{f}$ & $81.7 \mathrm{D}$ \\
\hline 90 ppm & 99.5 c & $91.3 \mathrm{de}$ & $106.5 \mathrm{~b}$ & $99.1 \mathrm{~B}$ & 96.3 de & $88.9 \mathrm{f}$ & $107.7 \mathrm{~b}$ & $97.5 \mathrm{~B}$ \\
\hline \multicolumn{9}{|l|}{ Interactions } \\
\hline Climax $\times 0$ ppm & 91.2 & 86.0 & 87.2 & 88.1 & 82.9 & 83.3 & 93.3 & 86.5 \\
\hline Climax $\times 30 \mathrm{ppm}$ & 98.0 & 91.4 & 99.3 & 96.3 & 90.1 & 90.9 & 104.7 & 95.2 \\
\hline Climax $\times 60$ ppm & 109.5 & 100.1 & 112.9 & 107.5 & 104.9 & 102.9 & 118.1 & 108.6 \\
\hline Meteor $\times 60 \mathrm{ppm}$ & 84.6 & 81.5 & 99.4 & 88.5 & 84.6 & 80.6 & 100.6 & 88.6 \\
\hline Meteor $\times 90$ ppm & 78.5 & 76.4 & 88.3 & 81.1 & 82.4 & 75.5 & 91.4 & 83.1 \\
\hline PF-400 × 0 ppm & 94.4 & 92.6 & 96.7 & 94.6 & 88.8 & 84.0 & 98.6 & 90.5 \\
\hline PF-400 × 30 ppm & 107.8 & 98.2 & 112.7 & 106.2 & 101.4 & 89.3 & 112.4 & 101.0 \\
\hline PF-400 × 60 ppm & 126.6 & 104.8 & 135.4 & 122.3 & 116.4 & 99.5 & 132.5 & 116.1 \\
\hline PF-400 × 70 ppm & 119.7 & 99.5 & 124.5 & 114.6 & 108.0 & 94.8 & 123.9 & 108.9 \\
\hline Means & $95.6 \mathrm{~B}$ & $89.4 \mathrm{C}$ & $101.6 \mathrm{~A}$ & & $91.5 \mathrm{~B}$ & $86.8 \mathrm{~B}$ & $103.0 \mathrm{~A}$ & \\
\hline
\end{tabular}

* Any two means with the same letter(s) in a column or row are non-significantly different at $P=0.05$ by Duncan's Multiple Range Test. ST: Seed treatment, FS: Foliar spray and STFS: Seed treatment plus foliar spray.

FW). Evaluating the application mode, the plants of the seed treatment plus foliar spray (STFS) responded with highest seed protein contents $\left(101.63 \mathrm{mg} \mathrm{g}^{-1} \mathrm{FW}\right)$ in $2013-14$, significantly different from plants exposed to only seed treatment (ST) $\left(95.63 \mu \mathrm{g} \mathrm{g}^{-1} \mathrm{FW}\right)$ or foliar spray (FS) $\left(89.44 \mu \mathrm{g} \mathrm{g}^{-1} \mathrm{FW}\right)$. All application modes were statistically different from each other in terms of seed protein content. In 2014-15, the protein content was highest for STFS plants (103.05 $\left.\mu \mathrm{g} \mathrm{g}^{-1} \mathrm{FW}\right)$ followed by ST ( $\left.91.55 \mu \mathrm{g} \mathrm{g}^{-1} \mathrm{FW}\right)$ and FS plants $\left(86.85 \mu \mathrm{g} \mathrm{g}{ }^{-1} \mathrm{FW}\right)$. A significant interaction between application modes and concentrations of silver nanoparticles was found in both growing seasons 2013-14 and 2014-15. The means for seed protein content varied from $82.08 \mu \mathrm{g} \mathrm{g}^{-1} \mathrm{FW}$ (FS plants, $0 \mathrm{ppm}$ ) to $115.95 \mu \mathrm{g} \mathrm{g}^{-1} \mathrm{FW}$ (STFS plants, AgNPs concentration $60 \mathrm{ppm}$ ) in 2013-14 and from $78.11 \mu \mathrm{g} \mathrm{g}^{-1} \mathrm{FW}$ (FS plants, AgNPs concentration $0 \mathrm{ppm}$ ) to $117.11 \mathrm{\mu g} \mathrm{g}^{-1} \mathrm{FW}$ (STFS plants, $60 \mathrm{ppm}$ ) in 2014-15.

The protein concentration in peas generally ranges from 15.5 to $39 \%$, depending on the varieties (Bressani and Elias 1988). Jabeen et al. (1988) studied different pea cultivars in Pakistan and recorded 20 to $22 \%$ of protein, since environmental factors affected the cellular protein pattern both qualitatively and quantitatively. Another study reported that increasing or decreasing enzymatic activity was directly related to corresponding proteins (Muntz 1996). The increasing demand for protein-rich products for human nutrition has attracted attention to this legume (Baniel et al. 1998). Results in this study revealed that the pea variety PF-400 treated with $60 \mathrm{ppm}$ AgNPs obtained maximum protein contents. The application of silver nanoparticles was found to stimulate seed protein contents. Earlier studies also proved an increase in protein contents in response to silver nanoparticle application. The effect of AgNPs on protein content in Phaseolus vulgaris and Zea mays has been studied (Salama 2012) and significant results were found. The results of Liu et al. (2010) also showed increases in protein contents with the application of ferric oxide nanoparticles.

Carbohydrates are a very important component of our diets. Pea seeds store about $43 \%$ of carbohydrates. The demand for pea varieties with a high percentage of carbohydrates is increasing day by day. In this study, a significant increase in carbohydrate of $P$. sativum seeds was found in response to the application of silver nanoparticles (Table 2). During the growing season 2013-14, the highest seed carbohydrate content was recorded for PF-400, while Climax and Meteor 
Table 2. Effect of AgNPs on carbohydrate contents ( $\mu \mathrm{g} \mathrm{g}^{-1} \mathrm{FW}$ ) of Pisum sativum L. (pea) varieties during the 2013-14 and $2014-15$ growing seasons

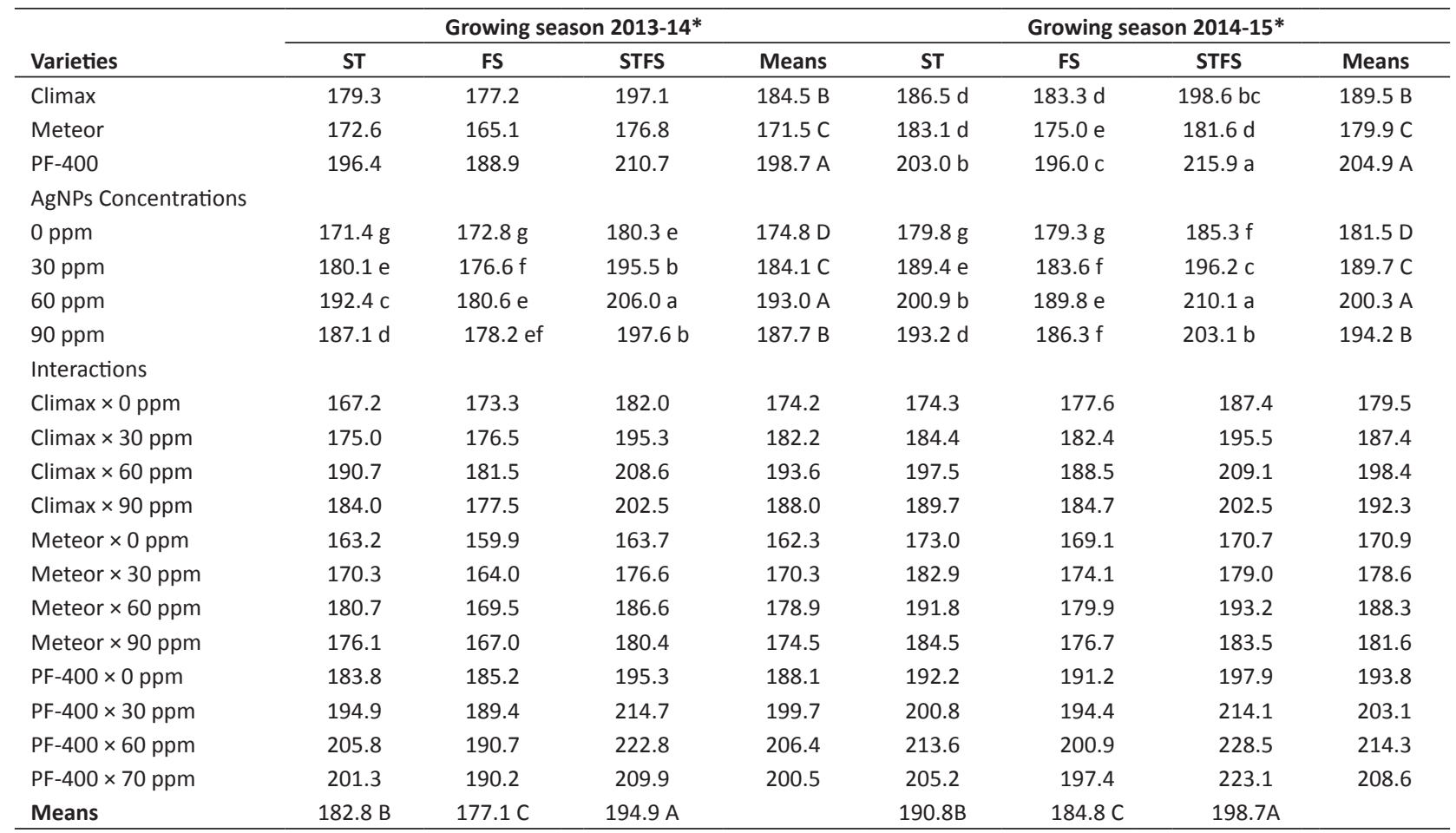

* Any two means with the same letter (s) in a column or row are non-significantly different at $P=0.05$ by Duncan's Multiple Range Test. ST: Seed treatment, FS: Foliar spray and STFS: Seed treatment plus foliar spray.

ranked $2^{\text {nd }}$ and $3^{\text {rd }}$ respectively. There were significant differences among all varieties in terms of seed carbohydrate content. The various concentrations of silver nanoparticles induced significant effects in the carbohydrate content of pea varieties in both growing seasons. During growing season 2013-14, higher carbohydrate contents (193.05 $\left.\mu \mathrm{g} \mathrm{g} \mathrm{g}^{-1} \mathrm{FW}\right)$ were found in plants treated with $60 \mathrm{ppm}$ AgNPs, statistically different from plants treated with $90 \mathrm{ppm}\left(187.70 \mu \mathrm{g} \mathrm{g}^{-1}\right.$ $\mathrm{FW}), 30 \mathrm{ppm}\left(184.12 \mu \mathrm{g} \mathrm{g}^{-1} \mathrm{FW}\right)$, and $0 \mathrm{ppm}\left(174.89 \mathrm{ug} \mathrm{g}^{-1} \mathrm{FW}\right)$ silver nanoparticles. All concentrations were significantly different from each other. Similar trends were found in the following year, when plants treated with 60 ppm AgNPs contained maximum carbohydrate contents $\left(200.38 \mathrm{\mu g} \mathrm{g}^{-1} \mathrm{FW}\right)$. With respect to the application mode, in the 2013-14 growing season, STFS plants had the highest carbohydrate content (194.92 $\left.\mu \mathrm{g} \mathrm{g}^{-1} \mathrm{FW}\right)$, followed by ST (182.80 $\left.\mu \mathrm{g} \mathrm{g}^{-1} \mathrm{FW}\right)$ and FS plants (177.10 $\left.\mathrm{mg} \mathrm{g}^{-1} \mathrm{FW}\right)$. During the 2014-15 growing season, the STFS plants had the highest carbohydrate content again (198.75 $\left.\mu \mathrm{g} \mathrm{g}^{-1} \mathrm{FW}\right)$, followed by ST (190.88 $\left.\mathrm{g} \mathrm{g}^{-1} \mathrm{FW}\right)$ and FS plants (184.80 $\left.\mu \mathrm{g} \mathrm{g}^{-1} \mathrm{FW}\right)$. Here the application modes also differed from each other statistically. A significant interaction was detected between modes of application and concentrations of silver nanoparticles during both growing seasons. The means for carbohydrate content of peas varied from $171.46 \mu \mathrm{g} \mathrm{g}^{-1} \mathrm{FW}$ (ST plant, 0 ppm AgNPs) to $206.08 \mu \mathrm{g} \mathrm{g}^{-1} \mathrm{FW}$ (STFS plants, $60 \mathrm{ppm}$ AgNPs) during 201314, and $179.36 \mu \mathrm{g} \mathrm{g}^{-1} \mathrm{FW}$ (FS, $0 \mathrm{ppm}$ AgNPS) to $210.10 \mu \mathrm{g} \mathrm{g}^{-1} \mathrm{FW}$ (STFS, $60 \mathrm{ppm}$ AgNPs) in the 2014-15 growing season.

During this study, highest carbohydrate seed contents were recorded in response to applications of $60 \mathrm{ppm}$ silver nanoparticles, significantly different from those of $90 \mathrm{ppm}$ and $30 \mathrm{ppm}$. Among the varieties, PF-400 accumulated highest carbohydrate contents after seed treatment plus foliar spray. Similar results were found in earlier studies. The study of Salama (2012) showed that an application of 60 ppm silver nanoparticles increased the carbohydrate content by 57 and $62 \%$ over the control in Phaseolus vulgaris and Zea mays plants, respectively. At 80 and 100 ppm however, significant decreases in carbohydrate content were recorded. The study of Liu et al. (2010) similarly reported that ferric oxide nanoparticles enhanced the carbohydrate amount in plants. However, contrary results were recorded for a treatment with zinc nanoparticles (Gokak and Taranath 2015). The carbohydrate contents were decreased in Abelmoschus esculentus 
Impact of biosynthesized silver nanoparticles on protein and carbohydrate contents in seeds of Pisum sativum L.

with the application of zinc nanoparticles from $100 \mathrm{ppm}$ to $500 \mathrm{ppm}$. This shows that the toxicity of nanoparticles depends on the type of nanoparticles as well as plant species.

Studies with $\mathrm{TiO}_{2}$ nanoparticles in Spinacia oleracea detected positive interactions with photosystems, especially an enhanced Rubisco activity (Zheng et al. 2005, Gao et al. 2006), while a Rubisco-limiting effect was detected with increasing concentrations of ferro fluid aqueous solution. This solution affected the growth of Zea mays at different photosynthetic stages by employing magnetic effect on the structures of enzymes (Racuciu and Creanga 2007).

\section{CONCLUSION}

This research describes the impact of AgNPs, synthesized using Berberis lycium root bark extract, on Pisum sativum seed metabolites. The biochemical seed analysis clearly showed that plants treated with AgNPs had greater seed protein and carbohydrate contents, resulting in better growth and yield. Furthermore, the phyto-based synthesis of nanoparticles was found to be rapid, inexpensive and enviro-friendly. The conclusion was drawn that the application of silver nanoparticles may be advantageous to plants, by guarding them against attacks of pathogens and as controlling diseases, although future research on the subject is required.

\section{REFERENCES}

Baniel A, Bertrand D, Lelion A and Gueguen J (1998) Variability in protein composition of pea seed studied by FPLC and multidimensional analysis. Crop Science 38: 1568-1575.

Benavides-Mendoza A, Ramirez-Rodriguez H, Robledo-Torres V, Hernandez-Davila J, Ramirez-Mezquitic JG, Bacopulos-Tellez E, Sandoval-Rangel A and Bustamante-Garcia MA (2002) Seed treatment with salicylates modifies stomatal distribution, stomatal density and the tolerance to cold stress in pepper seedlings. In Proceedings of the $16^{\text {th }}$ international pepper conference. Tampico, Mexico, p. 10-12.

Bobade KP, Kolte SO and Patil BG (1992) Affectivity of cyanobacterial technology for transplanted rice. Phykos 31: 33-35.

Bradford MM (1976) A rapid and sensitive method for the quantitation of microgram quantities of protein utilizing the principle of protein-dye binding. Analytical Biochemistry 72: 248-254.

Bressani R and Elias LG (1988) Seed quality and nutritional goals in pea, lentil, faba bean and chickpea breeding. In Summerfield RJ (ed) World crops: cool season food legumes. Springer, Dordrecht, p. 381-404.

Gao F, Hong F, Liu C, Zheng L, Su M, Wu X, Yang F, Wu C and Yang P (2006) Mechanism of Nano-anatase $\mathrm{TiO}_{2}$ on promoting photosynthetic carbon reaction of spinach: including complex of rubisco-rubisco activase. Biological Trace Element Research 111: 239-53.

Giraldo JP, Landry MP, Faltermeier SM, McNicholas TP, Iverson NM, Boghossian AA, Reuel NF, Hilmer AJ, Sen F, Brew JA and Strano MS (2014) Plant nanobionics approach to augment photosynthesis and biochemical sensing. Nature Materials 13: 400-408.

Gokak IB and Taranath TC (2015) Morphological and biochemical responses of Abelmoschus esculantus (L.) Moench to zinc nanoparticles. Advances in Natural Sciences: Nanoscience and Nanotechnology 6: 025017.

Gruère G, Narrod C and Abbott L (2011) Agriculture, food, and water nanotechnologies for the poor: opportunities and constraints, international food policy research institute. IFPRI Policy Brief 19: 1-4.
Gutierrez-Coronado MA, Trejo-Lopez C and Larque-Saavedra A (1998) Effects of salicylic acid on the growth of roots and shoots in soybean. Plant Physiology and Biochemistry 36: 563-565.

Hussain SA and Badshah N (2002) Study on the adaptive behaviour of exotic pea (Pisum sativum L.) varieties under local conditions of Peshawar. Asian Journal of Plant Sciences 1: 567-569.

Jabeen T, Iqbal P and Khalid IA (1988) Amino acid and mineral composition of pea cultivars grown in Peshawar. Pakistan Journal of Agricultural Research 9: 171-175.

Krishnaveni S, Balasubramanian T and Sadasivam S (1984) Sugar distribution in sweet stalk sorghum. Food Chemistry 15: 229-232.

Liu XM, Zhang FD, Zhang SQ, He XS, Fang R, Feng Z and Wang Y (2010) Effects of nano-ferric oxide on the growth and nutrients absorption of peanut. Plant Nutrition and Fertilizer Science 11: 14-18.

Muntz K (1996) Proteases and proteolytic cleavage of storage proteins in developing and germinating dicotyledonous seeds. Journal of Experimental Botany 47: 605-622.

Prasad R, Vivek K and Kumar SP (2014) Nanotechnology in sustainable agriculture: Present concerns and future aspects. African Journal of Biotechnology 13: 705-713.

Racuciu M and Creanga DE (2007) TMA-OH coated magnetic nanoparticles internalized in vegetal tissues. Romanian Journal of Physics 52: 395-402.

Salama HMH (2012) Effects of silver nanoparticles in some crop plants, common bean (Phaseolus vulgaris L.) and corn (Zea mays L.). International Research Journal of Biotechnology 3: 190-197.

Schlereth A, Becker C, Horstmann C, Tiedemann J and Müntz K (2000) Comparison of globulin mobilization and cysteine proteinases in embryonic axes and cotyledons during germination and seedling growth of vetch (Vicia sativa L.). Journal of Experimental Botany 51: 1423-1433.

Shankar SS, Rai A, Ahmad A and Sastry M (2004) Rapid synthesis of $\mathrm{Au}, \mathrm{Ag}$, and bimetallic $\mathrm{Au}$ core-Ag shell nanoparticles using Neem 
(Azadirachta indica) leaf broth. Journal of Colloid and Interface Science 275: 496-502.

Steel RGD, Dickey DA and Torrie JH (1996) Principles and procedures of statistics: a biomedical approach. McGraw-Hill, New York, 672p.

Teponno RB, Tapondjou AL, Gatsing D, Djoukeng JD, Abou-Mansour E, Tabacchi R, Tane P, Stoekli-Evans H and Lontsi D (2006) Bafoudiosbulbins $A$, and $B$, two anti-salmonellal clerodane diterpenoids from Dioscorea bulbifera L. var sativa. Phytochemistry 67: 1957-1963.

Urbano G, Aranda P, Gómez-Villalva E, Frejnagel S, Porres JM, Frías J, VidalValverde C and López-Jurado M (2003) Nutritional evaluation of pea (Pisum sativum L.) protein diets after mild hydrothermal treatment and with and without added phytase. Journal of Agricultural and Food Chemistry 51: 2415-2420.

Zargar M, Hamid AA, Bakar, FA, Shamsudin MN, Shameli K, Jahanshiri $F$ and Farahani $F$ (2011) Green synthesis and antibacterial effect of silver nanoparticles using Vitex negundo L. Molecules 16: 6667-6676.

Zheng L, Hong F, Lu S and Liu C (2005) Effect of nano-TiO ${ }_{2}$ on strength of naturally aged seeds and growth of spinach. Biological Trace Element Research 104: 83-92.

Zohary D and Hopf M (2000) Domestication of plants in the Old World: the origin and spread of cultivated plants in West Asia, Europe and the Nile Valley, Oxford University Press, United Kingdom, 328p. 